\title{
ESTIMATES OF ECONOMIC PERFORMANCE OF ORGANIC FOOD RETAIL TRADE
}

\begin{abstract}
As it is known, in recent years the phenomenon of "organic products" is getting more global and interdisciplinary character. The world has seen an increase of farmers' organic products, certification and the Earth's surface designed to produce organic products as well as sales of organic products. The role in the retail distribution of the produced organic products becoming a more significant.

Bearing all this in mind, this paper will deal, first, with the trend in retail development and characteristics of organic food observed globally, by country and formats (types of stores). Then we point out the key determinants of retail sales of organic food, and especially we will, as a primary goal of this paper, give a detailed overview of the theoreticalmethodological and empirical problems, as well as the specific measurement of financial performance of retail sales of organic food.

Research into these problems is, for the purpose of considering the practical dimensions, based on recent relevant empirical data. The research results should serve as the basis for the creation of appropriate policies and strategies and, especially, for building integrated system of managing business and financial performance of retail organic food in the future. This is particularly true for of retail originating from a country with the distinction in the market development of organic food, as is the case with Serbia.
\end{abstract}

Key words: organic food value chain, the reasons for buying organic food, organics food prices, premium prices, organic food efficiency distribution.

JEL Classification: D40 L81 M41

\section{INTRODUCTION}

The management of organic food is very important and complex. It can be studied from different angles. The literature that is devoted to this subject, is specifically examined from the perspective of organic food global market, the motives for purchasing organic foods, analyses of the value chain of organic food, cost and operational efficiency of production and distribution of organic food.

In the context of this study, the subjects are almost all of these aspects of organic food, with special emphasis on economic performance. The effort is made to explore these problems in the complex theoretical, methodological and empirical way. The goal is to create a good theoretical and methodological framework for more efficient management of organic food, and in the whole value chain, with special emphasis on retailers.

In this paper, among other things, provides the answer to the question: Why are costs of production and distribution of organic food so high? Are customers willing to pay the high

\footnotetext{
* Corresponding author.

Full Professor, Faculty of Economics, University of Belgrade, Kamenicka 6, Belgrade, Serbia. Scientific affiliation: Managerial Accounting and Retailing Management. Phone: +381 113021 112. E-maill addresses: rlukic@ekof.bg.ac.rs
} 
cost of organic food? Knowing the correct answer to these questions is a precondition for more efficient management of production and distribution of organic food.

\section{LITERATURE REVIEW}

It is a rich literature devoted to the analysis efficiency of production management and distribution of organic food. In addition to published articles on this topic in different highranking scientific and professional journals, there is a number of specialized institutes that are with more, because of its importance, more engaged in the research of key issues in the production and distribution of organic food.

Analysis of the effectiveness of the organization and functioning of most developed world markets organic food - through the relevant literature is the assumption for improving market efficiency in the development of organic food (Raynolds, 2004), as is the case of Serbia. Almost all developing countries, especially in transition, are characterized as markes in development of organic food.

All scientific and technical knowledge to that obtained in the literature, as well as the results of specialized institutes, are used in this work in the research of theoretical, methodological and empirical analysis of the efficiency problem of retail organic food.

\section{HYPOTHESES, METHODOLOGY AND EMPIRICAL DATA}

The management of the organic food business is very complex and can be studied from different aspects (economic, legal, medical) and studied by various research hypotheses. In this paper, the following research hypotheses are tested:

- The first hypothesis (H1): The influence of culture on the globalization of production and distribution of organic food.

- The second hypothesis (H2): The need to develop more effective marketing of organic food.

- The third hypothesis (H3): Specific features of structural change in retail organic food and its implication on their economic performances.

- The fourth hypothesis (H4): The development of a quality measurement system in order to improve business performance retail of organic food.

- The fifth hypothesis (H5): Identification and control of the key determinants of performance of retail of organic food.

When testing these hypotheses appropriate methodology is used. In addition to traditional methods, statistics and research methods are applied, primarily for quantification of effect of certain key factors (for example, the satisfaction of customers) on business performances of retail sales of organic food.

By applying the appropriate methodology, the study of individual hypothesis is based on relevant empirical data, primarily for countries with developed market for organic food. The results of the hypotheses should serve as a basis for creating the appropriate strategy for the development of retail organic food, especially in countries with characteristics - market in development of organic food.

The main objective of this work is to be based on analysis of available empirical evidence, review the specifics of the cost structure and financial structure of the retail organic food compared to other types of retailers. It should serve as a basis for creating the appropriate financial management strategies in retail organic food.

The basic methodology for studying the basic problems is a given ratio analysis. It is supported with appropriate statistical analysis. 
In this paper, all the tested hypotheses were confirmed. Developed a complex system of measures contribute to improving the performance of retail organic food.

Limiting the analysis of this type of problem is the lack of adequate empirical data. In addition to the literature that treats this problem is scarce.

\section{RESULTS}

\subsection{The globalization of organic food market}

General development characteristics of the phenomenon of "organic food" include: increase in farmers' organic food certification and area of arable land (in hectares) under organic food and organic food sales. It takes on more and more characteristics of the process of globalization (internationalization) production and distribution of organic food. Are shown in the Table 1 major international markets selling organic food.

Table 1 Leading organic food market

\begin{tabular}{|l|c|}
\hline \multicolumn{1}{|c|}{ Country } & $\begin{array}{c}\text { Sales } \\
\text { (in millions of euros) }\end{array}$ \\
\hline United States & 15,582 \\
\hline Germany & 5,850 \\
\hline France & 2,591 \\
\hline United Kingdom & 2,494 \\
\hline Italy & 1,970 \\
\hline Canada & 1,392 \\
\hline Switzerland & 905 \\
\hline Austria & 810 \\
\hline Denmark & 724 \\
\hline Sweden & 623 \\
\hline
\end{tabular}

Source: Kahl, J. et al., (2010), "Organic food claims in Europe", Food Technology, 3, p. 42.

From the data presented in a given table is clear that the United States is the world's leading country for market development of organic food.

Is characteristics for the United States the pace of increase in share of total sales of organic food (Table 2).

Table 2 The share of total sales of organic food in the United States, 2000-2009

\begin{tabular}{|c|c|}
\hline Year & The share of organic food in total sales (\%) \\
\hline 2000 & $1.2 \%$ \\
\hline 2001 & $1.4 \%$ \\
\hline 2002 & $1.6 \%$ \\
\hline 2003 & $1.9 \%$ \\
\hline 2004 & $2.2 \%$ \\
\hline 2005 & $2.5 \%$ \\
\hline 2006 & $2.9 \%$ \\
\hline 2007 & $3.2 \%$ \\
\hline 2008 & $3.6 \%$ \\
\hline 2009 & $3.7 \%$ \\
\hline
\end{tabular}

Source: NBJ Organic Data Report featuring OTA, Nutrition Business Journal, 2010. 
The comparison of certain products, there is the different structure of organic food sales in the United States. So, for example, the share of individual products in total sales of organic food in 2009 was the following: meat, poultry and fish $2 \%$; bread and cereals $11 \%$, fruit and vegetables $38 \%$, milk $15 \%$; spices $2 \%$, packaged and prepared foods $14 \%$; snacks 5\% and beverages 13\% (NBJ's 2010 Organic Featuring an OTA Data Report). The largest share, therefore, refers to fruits and vegetables.

Sales of organic food in the United States is different in (some) channels. So, for example, the share of individual channels in total sales of organic food in 2009 was the following: mass marketing retail (conventional retailers) 54\%, natural and special retail $40 \%$ and direct / exports 6\% (NBJ's 2010 Report Featuring Organic OTA Data). An increasing importance has been selling organic food in conventional stores.

Organic food stores are in many characteristics different from others in grocery retail (Table 3). They are characterized by prices that are high, the depth range of shallow-medium, the varieties of narrow-medium and the size of a small-medium.

Table 3 Characteristics of different types of retail stores in grocery

\begin{tabular}{|l|l|l|l|l|}
\hline Dimensions & Discount & Supermarket* & Organic food shop & Weekly Market \\
\hline Price & Low & Low-Medium & High & Low-high \\
\hline Depth range & Shallow & Medium-deep & Shallow-medium & Medium-deep \\
\hline Varietà & Narrow & Medium-wide & Narrow-Medium & Narrow-Medium \\
\hline Size & Small & Medium-large & Small-Medium & Small-large \\
\hline
\end{tabular}

* Includes a variety of formats of supermarkets, such as conventional supermarkets, and hypermarkets superstore.

Source: Zielke, S. (2010), " How price image dimensions influence shopping intentions for different store formats", European Journal of Marketing, Vol. 44, No. 6, p. 753.

By itself, due to the specific, supply chain management organic food is very complex. There is large number of members - a mediator in organic food supply chain of from farmer to retailer, restaurant or institution. Their participation in this is different (Tondel, 2006). It requests appropriate coordination between them in order to improve supply chain management of organic food, in order to minimize those activities that add no value.

One of the important features of organic food market is intense development - private brands. So, for example, the number of new organic products marked private brands has increased from 350 in 2003 to 540 in 2007 (Dimitri, 2009). Market share of private brands in retail milk (in the period 2004 - 2007) more than doubled: 2004 - 12\% and 2007 - 27\% (Dimitri, 2009). Private brand is one of the important factors to improve performance of retail organic food. The significant factors to improve performance of organic food retailing, in addition to private brands, include - the premium price. Table 4 of the sake of illustration, shows the premium price of milk in retail in the United States by individual months for 2007.

Table 4 Premium retail milk prices in the United States, 2007

\begin{tabular}{|l|l|l|l|l|}
\hline & \multicolumn{1}{|c|}{ March } & \multicolumn{1}{|c|}{ June } & \multicolumn{1}{|c|}{ September } & \multicolumn{1}{|c|}{ December } \\
\hline Organic price $*$ & 4.67 & $4: 32$ & $4: 45$ & $4: 40$ \\
\hline Conventional price * & $2: 06$ & $2: 24$ & $2: 46$ & $2: 43$ \\
\hline Premium * & 2.61 & $2: 08$ & 1.99 & 1.97 \\
\hline $\begin{array}{l}\text { Premium as a percentage of } \\
\text { conventional prices ** }\end{array}$ & $126 \%$ & $93 \%$ & $81 \%$ & $81 \%$ \\
\hline
\end{tabular}

Note: All prices are expressed in dollars per half gallon of milk. ** Author's calculation of the database, the source alleged.

Source: USDA, Economic Research Service calculations using Nielsen data. 
From the data presented in the given table we see much higher organic than conventional milk prices in the United States. This is the case with other organic products, whose prices contain high premiums. They (premium price) are treated as incentives for increase (efficiency) production and distribution of organic products.

In the last period there has been a growing trend of organic food sales in Europe. In Europe, market leader in organic food sales are Germany, France, the United Kingdom, and Italy (Table 1). In these countries, in other words, there is a significant share of organic food in the customer's total expenditures on food (Table 5).

Table 5 The share of organic in the customer's total expenditure for food in Europe, 2007

\begin{tabular}{|l|c|c|c|}
\hline \multicolumn{1}{|c|}{ Country } & $\begin{array}{c}\text { Organic food } \\
\text { expenses } \\
\text { mio } €\end{array}$ & $\begin{array}{c}\text { Share of total food } \\
\text { expenses } \\
\%\end{array}$ & $\begin{array}{c}\text { Organic food expense per } \\
\text { capita } \\
€\end{array}$ \\
\hline Germany & 5.300 & 3,7 & 64,4 \\
\hline France & 2.069 & 1,4 & 32,4 \\
\hline Italy & 1.387 & 1,0 & 21,4 \\
\hline The United Kingdom & 2.835 & 2,7 & 41,7 \\
\hline EU-15 & 14.381 & 1,9 & 35,9 \\
\hline
\end{tabular}

Source: An analysis of the EU organic sector, European Commission - Agriculture and Rural Development, June 2010.

Leading global retailers in Europe offer a number of diverse organic products and mostly have private own distinctive brand (Table 6). This is definitely a positive impact on their overall performance.

Table 6 Leading global retailers of organic products in Europe, 2003

\begin{tabular}{|l|l|l|l|}
\hline \multicolumn{1}{|c|}{ Retail chain } & \multicolumn{1}{c|}{ Country } & Number of items & \multicolumn{1}{c|}{ Private labels } \\
\hline Albert Heijn & The Netherlands & 275 & AH Biologisch \\
\hline Auchan & France & 700 & N / A \\
\hline Billa & Austria & 700 & Ja! Natürlich \\
\hline Carrefour & France & 800 & Carrefour Bio \\
\hline Coop Schweiz & Switzerland & 800 & Naturaplan \\
\hline Coop & Italy & 240 & Bio-logici \\
\hline Edeka & Germany & 500 & Bio-Wertkost, Bio-Gutfleisch \\
\hline Esselunga & Italy & 400 & Esselunga Bio \\
\hline Grona Konsum (KF) & Sweden & 1,200 & Anglamark \\
\hline Kesko & Finland & 500 & Pirkka \\
\hline Sainsbury's & The UK & 1,300 & Organic Sainsbury's \\
\hline SuperBrugsen (FDB) & Denmark & 1,300 & Natura Okologi \\
\hline tegut ... & Germany & 1,300 & tegut ... Bio \\
\hline Tesco & The UK & 1,300 & Tesco Organic \\
\hline
\end{tabular}

Source: Sahota (2004). By: Privato, S., Misano, N. and Tencati, A. (2008), "The imact of corporate social responsibility on consumer trust: the case of organic food", Business Ethics: A European Review, Volume 17, Number 1, p. 9.

In Europe - Germany is the leader in market development of organic food. Sales of organic food is done in specialized organic food stores, conventional supermarkets and directly to consumers (Table 7). 
Table 7 Market share of organic food marketing channels in Germany, 2008

\begin{tabular}{|l|c|}
\hline \multicolumn{1}{|c|}{ Marketing channels } & Market share (\%) \\
\hline Farmers & 8 \\
\hline Processors & 4 \\
\hline Health Food Stores & 3 \\
\hline Organic Food Stores & 22 \\
\hline General merchandise retailers & 57 \\
\hline Other & 6 \\
\hline
\end{tabular}

Source: www.organic-world.net/statistics-germany.html

In the United Kingdom (in the previous period) an upward trend in sales of organic food has been noticed. Sales of organic food in 2009 decreased compared to 2008 for 13.63\% probably because of the economic crisis ( Source: An analysis of the EU organic sector, European Commission - Agriculture and Rural Development, June 2010). This is the case, otherwise, and with other countries. The comparison of certain products, most of the sales is related to milk, fruit and vegetables and meat. Participation of other organic products is much lower.

In the United Kingdom, as in other countries, there are various channels of selling organic food (Table 8). Participation of multi-retailers (The Co-operative, Morrisons, Sainsbury's, Tesco, Waitrose) is dominant (73.7\%) in sales of organic food. Participation of other independent retailers is also significant (14.2\%). Sales of organic food is done electronically.

Table 8 The share of retail organic food market in the United Kingdom , 2009

\begin{tabular}{|l|c|}
\hline \multicolumn{1}{|c|}{ Marketing channel } & Market share (\%) \\
\hline Multiple retailers & $73.7 \%$ \\
\hline Box schemes/home deliver/mail order & $8.4 \%$ \\
\hline Farm shops & $1.8 \%$ \\
\hline Farmers' markets & $1.0 \%$ \\
\hline Catering & $0.9 \%$ \\
\hline Other independent retailers & $14.2 \%$ \\
\hline
\end{tabular}

Source: Soil Association - Organic market report 2010

Production and distribution of organic food in Serbia, compared to the United States and leaders in Europe is ata very low level (Source: Renko, N. et al. (2010), Deliverable No. 1.7 National report per country on the organic production on the basis of bibliography and data collection, June 2010, FOCUS-BALKANS, FP7 KBBE 20071 GA 212579 (www.focus-balkans.org).

It belongs to the so-called emerging markets. Over $90 \%$ of organic products are exported (Organic Agriculture in Serbia, GAIN Report Number: RB9002, 08/06/2009). In Serbia, sales of organic food is done in small special shops, in green markets and increasingly in supermarkets (43\%) and hypermarkets (Source: Renko, S., Marketing channels relation to organic products, Focus Balkans 4th Project Meeting Split, Croatia, Monday 1 st Februaray 2010). By comparing with neighboring countries, sales of organic food in Slovenia is done through the following channels: specialized organic food stores $18 \%$, conventional retailers $78 \%$ and other distribution channels 5\%, and in Croatia: specialized organic food stores 20\%, conventional retailers 75\% and other sales channels 5\% (Source:Vaclavik, T., Specialised Organic Retail Report Europe 2008, Compendium of Organic Market in 27 European Countries, ORA, February 20, 2009, BioFranch 09). In these countries the participation of 
specialized organic food stores is therefore less than $25 \%$ and the share of conventional retailers. Is high such a structure of channel sales of organic food will probably be in Serbia in the future, ie. Conventional retailers will have greater part in selling the organic food. All in all, there is a great potential for development of production and distribution of organic food in Serbia. Significant measures to improve efficiency of production and distribution of organic food in Serbia in the future include improving the legal framework, method of testing taste, quality organic food production, as well as higher budgetary allocations for the production and sale of organic food.

\section{2 Determinants of organic food sales performance}

By individual countries consumption of organic food is different. The consumption of organic food is influenced by numerous factors, market and political nature, and their intensity of impact varies from country to country. The market factors include (1) motives on the demand side (value orientation, concern for environmental protection, available food culture, level of income - growth) and (2) opportunities on the supply side (the soil and climate, relative prices, distribution channels). The policy factors include (1) regulations (EU-federal laws and regulations, national - state laws and regulations, subsidies) and (2) market development (control, certification, brand, information). (Thøgersen, 2010)

Research in practice sets out a number of reasons why customers buy organic foods. These are natural and unprocessed, restrictions on the use of pesticides, better taste, better for the good, better for the planet, etc. (Organic Market Report 2010, Soil Association).

Consumer's satisfaction and enthusiasm are important determinants of the sale and consumption of organic food. It affects economic performance (sales per square meter), frequency of purchase and recommendation. Factors that influence the customer satisfaction and enthusiasm are: product quality, customer service, store atmosphere, price satisfaction, protection of environment and location of stores (Bolten, J. et al., 2006). Their successful control can affect the level of customer satisfaction and enthusiasm and therefore the sale and the consumption of organic food. To illustrate, according to a study, (for example Germany) using the regression model showed that customers' satisfaction affects 32\% and customer's enthusiasm $27 \%$ of organic food sales per square meter (Table 9 ).

Table 9 Regression models for explaining economic performance in the retail organic food

\begin{tabular}{|c|c|c|}
\hline Independent variable & Beta & $\mathrm{t}$ \\
\hline Customer satisfaction & .62 & $2: 47 *$ \\
\hline \multicolumn{3}{|c|}{$\begin{array}{l}\text { Dependent variable: Annual sales per square meter of sales area. } \\
\text { Adjusted } \mathrm{R}^{2}=.32, \mathrm{~F}=6.11 *, * \mathrm{p} \leq .05\end{array}$} \\
\hline Independent variable & Beta & $\mathrm{t}$ \\
\hline Customer enthusiasm & .58 & $2.23 *$ \\
\hline
\end{tabular}

Source: Bolten, J. et al. (2006), "Perspectives of Small Retailers in the Organic Market: Customer Satisfaction and Customer Enthusiasm," Paper prepared for presentation at the 98th EAAE Seminar 'Marketing Dynamics within the Global Trading System: New Perspectives', Chania, Grete, Greece as in 29 June-2 July, 2006.

Customers with higher incomes and education, as well as older families (due to health) buy more organic products. Customers tend to buy fewer organic products when they buy concentrates. Customers tend to buy more products marked private brands than the national. The promotion of private brands affects increased sales of organic food. The price inversely affects sales of organic food (Ngobo, 2010). 
Effective managing of the development of private brands of organic products is very complex because of the pro-and anti-competitive effect (Table 10). But no matter, in any case the development of private brands is a significant factor in sales performance of organic products.

Table 10 Pro-and anti-competitive impact of private brands of organic products

\begin{tabular}{|l|l|l|}
\hline \multicolumn{1}{|c|}{ Relation from } & \multicolumn{1}{|c|}{ Pro-competitive impacts } & \multicolumn{1}{c|}{ Anti-competitive impact } \\
\hline $\begin{array}{l}\text { Manufacturer- } \\
\text { retailer }\end{array}$ & $\begin{array}{l}\text { Lower prices at high quality; } \\
\text { Improving supply chain } \\
\text { management; } \\
\text { Facilitation entry }\end{array}$ & $\begin{array}{l}\text { Flexibility loss due to vertical } \\
\text { integration }\end{array}$ \\
\hline Retail & $\begin{array}{l}\text { High margin / rate of return; } \\
\text { Distinction from competitiors; } \\
\text { Price pressure }\end{array}$ & $\begin{array}{l}\text { Turnover losses for conventional } \\
\text { products }\end{array}$ \\
\hline Retail - consumer & $\begin{array}{l}\text { Diffusion of organic products; } \\
\text { Consumer loyalty }\end{array}$ & $\begin{array}{l}\text { Lower-cost imitations; } \\
\text { PL as strategic weapon; } \\
\text { Insufficient communication }\end{array}$ \\
\hline
\end{tabular}

Note: PL is a group of organic products: nutriments, fruits and vegetables, meat and fish, dairy products, juices, oil, fat and parfaits and natural stimulants. The share of these organic retail products is very significant.

Source: Janas. A. and Roosen, J. (May 2004), "Private labels for premium products - the axample of organic food," Working Paper EWP 0404, Department of Food Economics and Consumption Studies, University of Kiel.

\section{3 Specifics of the financial structure and profitability of the retail organic food}

The organic food retail key determinants of overall financial performance are: the efficient management of liquidity, indebtedness, margin, operating expenses and profit.

It is known that organic sales price are higher than non-organic products. Why is this so? The cause of the high input costs of organic products, high margin, and the willingness of customers to - for some reason - buy them at that price.

By its nature margin as the difference between sales and cost of goods sold is one of the very important indicators of overall performance - profitability of retail organic food. It is generally speaking, used to cover operating costs and achieve a certain profit for the growth and development.

Cost structure of retail organic food is specific in relation to other retail sectors, ie. product categories (Table 11).

Table 11 Comparative performance in retail health food

\begin{tabular}{|l|l|l|l|}
\hline & \multicolumn{3}{|c|}{ Annual turnover range } \\
\hline $\begin{array}{l}\text { Benchmark } \\
\text { Comparison) }\end{array}$ & Low & $\begin{array}{l}\text { Medium } \\
\$ 75,000-\$ \\
150,000-\$\end{array}$ & $\begin{array}{l}\text { High } \\
\$ 600,000-\$ \\
6,000,000\end{array}$ \\
\hline $\begin{array}{l}\text { Cost of goods sold / } \\
\text { turnover }\end{array}$ & $52 \%-64 \%$ & $57 \%-65 \%$ & $59 \%-65 \%$ \\
\hline Work / turnover & $0 \%-9 \%$ & $3 \%-13 \%$ & $10 \%-16 \%$ \\
\hline Rent / turnover & $6 \%-16 \%$ & $6 \%-12 \%$ & $7 \%-11 \%$ \\
\hline
\end{tabular}

Three main categories of costs in the retail organic food are: the cost of goods sold, labor and rent. Their effective management can, therefore, cause an increase in retail profit of organic food. 
Specifics of the financial structure and profitability of retail organic food in this work we will demonstrate global business retailer Whole Foods Market, which operates with 275 stores in 38 states (Table 12).

Table 12 Historical performance of Whole Foods Market

\begin{tabular}{|l|l|l|l|l|l|l|l|l|l|l|}
\hline \multicolumn{1}{|c|}{ Metric } & 2000 & 2001 & 2002 & 2003 & 2004 & 2005 & 2006 & 2007 & 2008 & 2009 \\
\hline $\begin{array}{l}\text { Store number at the end of the } \\
\text { year }\end{array}$ & 145 & 145 & 135 & 126 & 163 & 175 & 186 & 276 & 275 & 284 \\
\hline Comp Store Sales Growth & 8.6 & 9.2 & 10.0 & 8.6 & 15.0 & 12.8 & 11.0 & 7.0 & 4.9 & \\
\hline $\begin{array}{l}\text { Average Store Size ('000 } \\
\text { Square Feet) }\end{array}$ & 22 & 25 & 30 & 36 & 32 & 33 & 34 & 34 & 36 & 37 \\
\hline \\
$\begin{array}{l}\text { Source: Chacon, F. , SBDCNet Connections Issue 57: Retail Organic Food Industry in the United States, March 2010, NAICS Code: } \\
\text { 445299, SIC Code: 5499 (www.sbdcnet.org) }\end{array}$
\end{tabular}

Table 13 shows key financial indicators for the analysis of financial health of Whole Foods Market.

Table 13 Key financial indicators of Whole Foods Market, 2009.

\begin{tabular}{|l|l|l|}
\hline & Whole Foods Market & Industry \\
\hline Liquidity ratios & & \\
\hline Angry ratio & 0.8 & 0.3 \\
\hline Current ratio & 1.5 & 1 \\
\hline Leverage ratios & & \\
\hline The long-term debt / equity & 0.45 & 1.03 \\
\hline Total debt / equity & 0.45 & 1.14 \\
\hline Total debt / assets & 0.57 & - \\
\hline Activity ratios & & \\
\hline Asset turnover & 2.2 & 2.6 \\
\hline Turnover of receivables & 7.3 & 50.2 \\
\hline Fixed Assets Turnover & - & - \\
\hline Inventory turnover & 15.7 & 12.1 \\
\hline The average collection period of receivables (days) & 73 & 50.2 \\
\hline Profitability ratios & & \\
\hline Return on sales & 3.9 & 0.6 \\
\hline Return on investment & 6.2 & 1 \\
\hline Return on equity & 5.9 & 2.8 \\
\hline Earnings per share & 70.6 & - \\
\hline Income from dividends & 0 & 1.7 \\
\hline Payment of dividends & 0 & 2.4 \\
\hline Price / Earnings & 36.6 & 142.8 \\
\hline
\end{tabular}

Source: Onley, M. (March 5, 2010), "Qualitative and Quantitative Analysis of Whole Foods Market, Regis University.

From the data presented in the given table we see - compared to the average - much better liquidity, financial indebtedness and profitability of Whole Foods Market. In other words this means, , that the management of any profit was satisfactory, as well as asset turnover (total for all forms) and financial indebtedness, viewed as a component of so-called strategic profit model. 
The retailer Wal-Mart also sells more organic products and is one of the strong competitors. It has a comparative advantage over other competitors in terms of distribution networks and suppliers' price control capabilities. This affects the rate of gross margin WalMart which is (23.1\%) lower than that of Whole Foods Market (35.0\%). (Source: Chacon, F. , SBDCNet Connections Issue 57: Retail Organic Food Industry in the United States, March 2010, NAICS Code: 445299, SIC Code: 5499 (www.sbdcnet.org)

Profitable performance of the retailer Whole Foods Market could improve, among other things, with efficient management of operating costs. This is especially true for the direct costs of stores, which dominate in the total operating costs (Table 14). It contributes greatly to the use of modern information and communication technology, and efficient human resources management.

Table 14 Operational performance of Whole Foods Market (as a percentage of sales)

\begin{tabular}{|l|l|l|l|}
\hline & 2009 & 2008 & 2007 \\
\hline Sales & $100 \%$ & $100 \%$ & $100 \%$ \\
\hline Cost of goods sold and occupancy costs & 65.7 & 66.0 & 65.2 \\
\hline Gross profit & 34.3 & 34.0 & 34.8 \\
\hline Direct store expenses & 26.7 & 26.5 & 26.0 \\
\hline General and administrative expenses & 3.0 & 3.4 & 3.3 \\
\hline Pre-opening expenses & 0.6 & 0.7 & 0.9 \\
\hline Relocation, store clousure and lease termination costs & 0.4 & 0.5 & 0.2 \\
\hline Operating incomes & 3.5 & 3.0 & 4.5 \\
\hline Interest expense & $(0.5)$ & $(0.5)$ & $(0.1)$ \\
\hline Investment and other income & - & 0.1 & 0.2 \\
\hline Income before income taxes & 3.1 & 2.6 & 4.6 \\
\hline Provision for income taxes & 1.3 & 2.6 & 4.6 \\
\hline Net income & 1.8 & 1.4 & 2.8 \\
\hline Preferred stock dividends & 0.3 & - & - \\
\hline Income available to common shareholders & $1.5 \%$ & $1.4 \%$ & $1.8 \%$ \\
\hline
\end{tabular}

Note: Amounts due to rounding are not equal to the sum of the constant number 100

Source: 2009 Annual Report.

\section{CONCLUSION}

Because of its importance, the process of globalization of the market of all organic products, which means food too have been expressed lately. According to the realized sales, a leading organic food market in the world, Are the United States, Germany, France, United Kingdom, and Italy. Knowledge of their achievements in this area is very important for effectively management of the emerging markets of organic food, as is the case with Serbia. In the function of an efficient market development of organic food in Serbia in the future it is necessary, like in this country, to improve regulations, methods for testing the taste, quality and much higher budget allocations for these purposes.

Prices of organic food have been known higher when more as compared to conventional. Margins and input costs of organic food are also higher. Three major categories of organic food retailing costs are: costs of goods sold, labor and rent. In addition to organic prices, premium rates, customer satisfaction and the development of private brands are important as well determinants of organic food sales. 
Sales of organic food is done in specialized stores, conventional supermarkets and hypermarkets and direct customers. In all countries, increases, the participation of conventional retailers in selling organic foods is increased.

Based on the empirical research - the case of Whole Food Market, general conclusion: is that organic food retailers are in a position to get almost all the indicators of very positive financial performance (liquidity, solvency, profitability), well above average. The causes of this are, among other things, high prices, margins and effectively managing costs and available capital. In the future they will be largely determined by the degree of application of modern information technology and communication. Identification and effective management of all the key determinants is therefore a prerequisite for efficient management of overall performance in the retail organic food.

\section{REFERENCES}

An analysis of the EU organic sector, European Commission - Agriculture and Rural Development, June 2010.

Berman, B. and Evans, J. R. (2010), Retail Management, Prentice Hall, Boston.

Bolten, J. et al. (2006), "Perspectives of Small Retailers in the Organic Market: Customer Satisfaction and Customer Enthusiasm", Paper prepared for presentation at the 98th EAAE Seminar ' Marketing Dynamics within the Global Trading System: New Perspectives', Chania, Grete, Greece as in: 29 June-2 July, 2006.

Chacon, F. , SBDCNet Connections Issue 57: Retail Organic Food Industry in the United States, March 2010, NAICS Code: 445299, SIC Code: 5499 (www.sbdcnet.org).

Chakrabarti, S. (2010), "Factors influencing organic food purchase in India - expert survey insights", British Food Journal , Vol. 112, No.8, pp. 902-915.

Dimitri, C. and Oberholtzer, L. (September 2009), "Marketing US Organic Foods, Recent Trends From Farms to Consumers", United States Department of Agriculture - USDA, Economic Research Service, Economic Information Bulleten - EIB Number 58.

Health food retailing, 27 April 2010.

Hughner, R. Sh. et al. (2007), "Who are organic food consumers? A compilation and review of why people purchase organic food", Journal of Consumer Behaviour, 6, pp.94-110.

Janas. A. and Roosen, J. (May 2004), "Private labels for premium products - the example of organic food", Working Paper EWP 0404, Department of Food Economics and Consumption Studies, University of Kiel.

Kahl, J. et al., (2010), "Organic food claims in Europe", Food technology, 3, pp. 38-46.

Kottila, M. R. (2010), Understanding the Organic Chain, Academic Dissertation, University of Helsinki.

Lakhal, S. L. et al. (2008), "Coparing conventional and sertified organic cotton supply chains: the case of Mali", Int. J. Agricultural resources, Governance and Ecology, Vol. 7, No. 3, pp.243-255.

Levy, M. and Weitz, M. (2007), Retailing Maangement, McGraw-Hill, Boston.

NBJ Organic Data Report featuring OTA, Nutrition Business Journal, 2010.

Ngobo, PV (2010), " What Drives Household Choice of Organic Products in Grocery Stores?", Journal of Retailing , xxx (xxx), xxx-xxx (doi:10.1016/j.jretai.2010.08.001).

Onley, M. (March 5, 2010), "Qualitative and Quantitative Analysis of Whole Foods Market, Regis University.

Onley, M. (March 5, 2010), "Qualitative and Quantitative Analysis of Whole Foods Market, Regis University. 
Privato, S., Misani, N. and Tencati, A. (2008), "The imact of corporate social responsibility on consumer trust: the case of organic food", Business Ethics: A European Review , Volumen 17, Number 1, pp. 3-12.

Raynolds, LT (2004), "The Globalization of Organic Agro-Food Networks", World Development, Vol. 32, No. 5, pp. 725-743.

Rieple, A. and Singh, R. (2010), "A value chain analysis of the organic cotton industry: The case of UK retailers and Indian suppliers", Ecological Economics, 69, pp. 2292-2302.

Sahota (2004). By: Privato, S., Misano, N. and Tencati, A. (2008), "The imact of corporate social responsibility on consumer trust: the case of organic food", Business Ethics: A European Review, Volume 17, Number 1.

Sirieix, L. and Schaer, B. (2005), "Buying organic food in France: shopping habits and trust”,Working Paper 1, Unite' Mixte de Recherche MOISA, Montpellier.

Smith, E. and Marsden, T. (2004) , "Exploring the 'limits to growth' in UK organics: beyond the statistical image", Journal of Rural Studies, 20, pp.345-357.

Smith, T. A. et al. (2009), "Growth and Development in the US Retail Organic Food Sector", Sustainability , 1, pp. 573-591 (doi:10.3390/su 1030573).

Smith, T. A. et al. (2009), "How much are consumers Paying for Organic Baby Food ?" Selected Paper prepared for presentation at the Southern Agriculture Economics Association Annual Meeting, Atlanta, Georgia, January 31-February 3, 2009.

Soil Association - Organic market report 2010.

Thøgersen, J. (2010), " Country Differences in Sustainable Consumption: The Case of Organic Food", Journal of Macromarketing , Volume 30, Issue 2, pp. 171-185.

Tondel, F. and Woods, T. (2006), "Supply Chain Mangemnet and the Changing Structure of US Organic Produce markets", Selected paper prepared for presentation at the American Agricultural Economics Association Annual Meeting, Long Beach, California, July 23-26, 2006.

USDA, Economic Research Service calculations using Nielsen data.

Whole Foods Market: 2009 Annual Report.

Zielke, S. (2010), " How price image dimensions influence shopping intentions for different store formats", European Journal of Marketing , Vol. 44, No. 6, pp. 748-770. 


\section{PROCJENE EKONOMSKIH PERFORMANSI TRGOVINE NA MALO ORGANSKE HRANE}

\section{SAŽETAK}

Kao što je poznato, u novije vrijeme fenomen "organski proizvodi" poprima sve više globalni i interdisciplinarni karakter. U svijetu je zabilježen porast broja farmera organskih proizvoda, certifikata i zemljine površine namijenjene za proizvodnju organskih proizvoda, kao i prodaje organskih proizvoda. Sve je značajnija $i$ uloga maloprodaje $u$ distribuciji proizvedenih organskih proizvoda.

Imajući sve to $u$ vidu, u ovom radu osvrnut ćemo se, prvo, na trend i karakteristike razvoja maloprodaje organske hrane promatrano globalno, po pojedinim zemljama i formatima (tipovima prodavaonica). Zatim ćemo ukazati na ključne determinante razvoja maloprodaje organske hrane. I na kraju ćemo se, kao primarni cilj ovog rada, detaljno osvrnuti na teorijsko-metodološke $i$ empirijske probleme, kao $i$ na specifičnosti mjerenja financijskih performansi maloprodaje organske hrane.

Istraživanje ovih problema je, $u$ svrhe sagledavanja praktične dimenzije, zasnovano na najnovijim relevantnim empirijskim podacima. Pri tom je primijenjena prije svega najednostavnija tradicionalna metodologija istraživanja. Dobiveni istraživački rezultati trebaju poslužiti kao osnova za kreiranje odgovarajuće politike i strategije razvoja $i$, posebno, za izgradnju integralnog sustava upravljanja poslovnim i financijskim performansama trgovine na malo organskom hranom u budućnosti. To se posebno odnosi na maloprodaju porijeklom iz zemlje sa odlikom tržišta u razvoju organske hrane, kakav je slučaj sa Srbijom.

Ključne riječi: lideri tržišta organske hrane, lanac vrijednosti organske hrane, razlozi kupnje organske hrane, premija cijene organske hrane, privatna robna marka, učinkovitost distribucije organske hrane.

JEL : D40 L81 M41 